\title{
Effects of daily curve and age on intraocular pressure in Criollo horses
}

\section{Efeitos da curva diária e da idade na pressão intraocular em cavalos Crioulos}

\author{
Ângela Beatriz de Oliveira Bacchin'; Géssica Maria Ribeiro da Silva1; Maiara

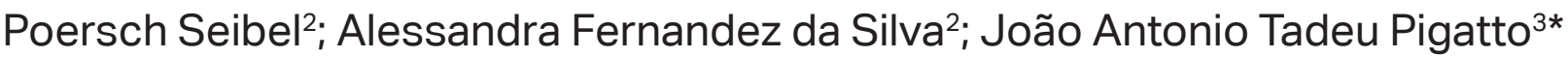

\section{Highlights}

Tonometry was used in healthy Criollo horses throughout the day.

Values of intraocular pressure were compared in relation to animal age.

Older horses showed reduced intraocular pressure.

\begin{abstract}
The objective of this study was to evaluate the intraocular pressure (IOP) of healthy Criollo horses using a rebound tonometer throughout the day. In addition, assessments were made in horses of different ages. Twenty-seven horses, male and female, were divided into three groups by age: Group I (3-5 years old), Group II (6-8 years old), and Group III: (9-16 years old). Ophthalmic examinations were performed using the Schirmer tear test, slit-lamp biomicroscopy, fluorescein test and indirect ophthalmoscopy. Seven measurements of IOP were assessed on the same day (at 6:00 am, 9:00 am, 12:00 am, 3:00 pm, 6:00 pm, 9:00 pm and 00:00 pm). A t-test was used when there were two groups of comparisons and ANOVA was used to detect differences in IOP between measurement times and between age categories. The average IOP was $28.4 \pm 3.7 \mathrm{mmHg}$ for all eyes. The mean IOP for Groups I, II and III were $29.2 \pm 3.5,28.4 \pm 4.3$ and $27.7 \pm 3.2 \mathrm{mmHg}$, respectively. There was no statistically difference between right and left eyes. There was a significant difference between Group I and Group III ( $P=0.008)$. There were no statistically significant differences between measurements recorded at different times of the day $(P=0.560)$. The IOP was not influenced by the circadian rhythm, but older horses showed reduced IOP.
\end{abstract}

Key words: Rebound tonometry. Intraocular pressure. Equine.

1 Master Students of the Postgraduate Program in Animal Medicine, Horses, Faculty of Veterinary Sciences, Federal University of Rio Grande do Sul, UFRGS, Porto Alegre, RS, Brazil. E-mail: angela.bacchin@terra.com.br; gessica06@ gmail.com

2 Undergraduate Students, Faculty of Veterinary Sciences, UFRGS, Porto Alegre, RS, Brazil. E-mail: maiarapoersch@ hotmail.com; alessandra-fsilva@hotmail.com

${ }^{3}$ Prof. Dr., Department of Animal Medicine, Faculty of Veterinary Sciences, UFRGS, Porto Alegre, RS, Brazil. E-mail: pigatto@ufrgs.br

* Author for correspondence

Received: May 03, 2020 - Approved: Feb. 09, 2021 


\section{Resumo}

O objetivo deste estudo foi avaliar a pressão intraocular (PIO) com um tonômetro rebote em cavalos da raça Crioula ao longo do dia. Além disso, foram realizadas avaliações em cavalos de diferentes idades. Vinte e sete cavalos, machos ou fêmeas foram divididos em três grupos de acordo com a idade: Grupo I (3 a 5 anos), Grupo II (6 a 8 anos) e Grupo III (9 a 16 anos). O exame oftálmico incluiu teste da lágrima de Schirmer, biomicroscopia com lâmpada de fenda, prova da fluoresceína e oftalmoscopia indireta. Sete medidas de PIO foram realizadas no mesmo dia (às $6 \mathrm{~h}, 9 \mathrm{~h}, 12 \mathrm{~h}, 15 \mathrm{~h}, 18 \mathrm{~h}, 21 \mathrm{~h}$ e $24 \mathrm{~h}$ ). $\mathrm{O}$ teste $\mathrm{t}$ foi usado quando havia dois grupos de comparações e a análise de variância (ANOVA) foi usada para detectar diferenças na PIO entre os momentos de medição e entre as categorias de idade. A PIO média foi de $28,4 \pm 3,7 \mathrm{mmHg}$ para todos os olhos. A PIO média dos grupos I, II e III foi de 29,2 $\pm 3,5,28,4 \pm 4,3$ e 27,7 $\pm 3,2 \mathrm{mmHg}$, respectivamente. Não houve diferença estatística entre os olhos direito e esquerdo. Houve diferença entre o grupo I e o grupo III $(P=0,008)$. Não houve diferença entre as medidas registradas em diferentes momentos do dia $(P=0,560)$. A PIO aferida com tonômetro de rebote em cavalos da raça Crioula saudáveis não sofreu influência da hora do dia em que foi realizada, mas foi menor em equinos mais velhos.

Palavras-chave: Tonometria de rebote. Pressão intraocular. Equino.

Intraocular pressure (IOP) is determined by the production and drainage of the aqueous humour. Normal IOP values measured using a rebound tonometer in horses oscillate between 10 and $34 \mathrm{mmHg}$ (Holve, 2012). Tonometry is a measure of intraocular pressure and is important during ophthalmic examination, especially in patients suspected to have uveitis or glaucoma (Ramsey, Hauptman, \& Petersen-Jones, 1999; Komáromy, Garg, Ying, \& Liu, 2006). Normally IOP values are obtained in animals using applanation and rebound tonometers (Diehl \& Bowden, 2020). In rebound tonometry, the measurement of IOP is made by a probe that touches the cornea and automatically calculates the mean value of IOP. Rebound tonometry is well tolerated by animals and there is no need for topical anaesthesia (Holve, 2012).

Mean IOP values may be influenced by numerous factors, including the type of tonometer used, the examiner's experience, patient species, age of the animal and the time of day at which IOP is measured, among others (Komáromy et al., 2006; Diehl \& Bowden, 2020). Other factors, such as ocular disease, systemic blood pressure, the use of cycloplegic agents and the application of intravenous sedatives, also alter IOP (Pereira, Bercht, Soares, da Mota, \& Pigatto, 2011; Andrade, Hünning, Pereira, Dutra, \& Pigatto, 2016). The circadian rhythm is influenced by light because when it reaches the retina the central nervous system regulates melatonin levels, which are greater at night and reduce the production of aqueous humour during this period (Huet-Toral, Crooke, Martínez-Águila, \& Pintor, 2015). Studies have been carried out to identify IOP variation due to circadian rhythm (Bertolucci, Giudice, Fazio, \& Piccione, 2009; Piccione, Giannetto, Fazio, \& Giudice, 2010; Pereira et al., 2011). However, there is no consensus on his influence on IOP values in animals (Pereira, et al al., 2011). Oscillation in IOP is a risk factor for patients with glaucoma, and the identification of peaks can be used in the management of antiglaucoma therapy. In many species there is 
an inverse correlation between age and IOP, probably due to the decrease in the production of aqueous humour (Marzok \& El-Khodery, 2015). The evaluation of IOP has increasingly been a part of the ophthalmic examination of horses (Ramsey et al., 1999; Komáromy et al., 2006; Holve, 2012). The time of day when tonometry is performed is important not only for diagnosis but also for the treatment of eye diseases (Piccione et al., 2010). The Criollo breed was included in the present study due to the large number of animals bred and also to the existence of few studies regarding this breed and tonometry.

The objective of this study was to measure IOP in healthy Criollo horses of different ages at different times during the day using a rebound tonometer. Moreover, we hypothesise that there is a difference in IOP based on the age of the animals tested.

Twenty-seven horses, males and females of the Criollo breed, of different ages from Cabanha São Caetano (Porto Alegre, RS, Brazil) were employed in this study. The experiment was carried out on healthy athletic horses. All were considered healthy based on physical examination findings and the results of blood tests, which were within reference ranges reported for the species. The study followed the ethical norms of the Association for Research in Vision and Ophthalmology [ARVO] (2016) and was approved by the Committee of Ethics in the Use of Animals (CEUA) of the Federal University of Rio Grande do Sul. Before the start of the experiment, all animals were submitted to ophthalmic examination.

During ophthalmic evaluation, the Schirmer tear test (TLS; Teste Lacrimal de Schirmer, Ophthalmos, SP, Brazil), biomicroscopy using a portable slit lamp (Portable Slit Lamp SL15, Kowa, Japan), detection of fluorescein (Fluorescein strips, Ophthalmos, SP, Brazil), and an indirect ophthalmoscopy were performed. Only horses that had clinically normal eyes were selected.

A rebound tonometer was used to measure tonometry (TonoVet ${ }^{\circledR}$, Tiolat, Helsinki, Finland). The equipment was calibrated in $\mathrm{h}$-mode, which is specific for equine species. The selected animals were divided into three groups according to age; each group consisted of nine horses. Group I was formed by horses between 3 and 5 years of age (with an average age of 4.7 years) containing seven females and two males; Group II comprised horses between 6 and 8 years (with an average age of 7.1 years) containing four females and five males; and Group III comprised horses between 9 and 16 years (with an average age of 11.6 years) containing two females and seven males. The evaluation of IOP was performed on the right and left eyes of each animal. Each horse was subjected to seven measurements of IOP on the same day (at 6:00 am, 9:00 am, 12:00 am, 3:00 pm, 6:00 pm, 9:00 pm and 00:00 pm) and evaluated over 6 days. The order of eyes and horses examined were chosen in a randomised manner. All measurements of IOP were made by the same examiner and were taken within the stall of each horse. During tonometry, the head of each horse was kept in a neutral position without pressure on the jugular veins.

The containment was carried out by the same auxiliary. Measurements at 6:00 am, 9:00 am, 12:00 am and 3:00 pm were performed under natural light and the rest with the use of a flashlight. In the place where the research was carried out, the sun rose at 05:16 am and set at 06:23 pm.The natural light 
came from a window in each stable. From 6:00 pm, the artificial light in the stables was turned off. During the tonometry, flashlights with red filters were used. The animals were evaluated one month after the experiment ended and no ocular changes related to IOP measurement were observed.

The data were compiled and analysed using SPSS ${ }^{\circledR}$ software (18.0 version, Chicago, IL; Statistical Package for the Social Sciences). Normality of the distribution of variables was confirmed by the Kolmogorov-Smimov test. A t-test was used to compare IOP values in left and right eyes and in males and females. ANOVA followed by Tukey's test was used to compare ages and distinguish between the hours of the day at which differences in IOP were seen. All the tests were employed considered a level of significance of $5 \%$.

It was possible to perform tonometry on all the horses selected for the study. All measurements were recorded without the need of a twitch to contain the animals. The mean IOP of the 27 animals was $28.4 \pm 3.7$ $\mathrm{mmHg}$ and the mean IOPs of right and left ocular bulbs were $27.9 \pm 3.6$ and $29.1 \pm 3.8$ $\mathrm{mmHg}$, respectively. No significant statistical differences were observed when the values obtained in the left eye were compared with the values obtained in the right eye $(P=0.257)$.

The mean IOP of females and males was $29.2 \pm 3.7$ and $27.6 \pm 3.6 \mathrm{mmHg}$, respectively, with no difference between them $(P=0.284)$. The mean IOP values for groups I, II and III were $29.2 \pm 3.5,28.4 \pm 4.3$, and $27.7 \pm 3.2 \mathrm{mmHg}$, respectively (Table 1 ). There was a significant difference between Group I and Group III (P = 0.008).

IOP was measured throughout the day and was $27.5 \pm 3.1 \mathrm{mmHg}$ at $6: 00 \mathrm{am}, 29.3 \pm 4.1$ $\mathrm{mmHg}$ at 9:00 am, $29.1 \pm 3.5 \mathrm{mmHg}$ at 12:00 am, $28.9 \pm 3.7 \mathrm{mmHg}$ at 3:00 pm, $28.6 \pm 4.0$ $\mathrm{mmHg}$ at $6: 00 \mathrm{pm}, 27.4 \pm 3.8 \mathrm{mmHg}$ at 9:00 $\mathrm{pm}$, and $28.2 \pm 3.5 \mathrm{mmHg}$ at 00:00 pm. The time when tonometry was recorded had no statistical influence on IOP $(P=0.560)$. 


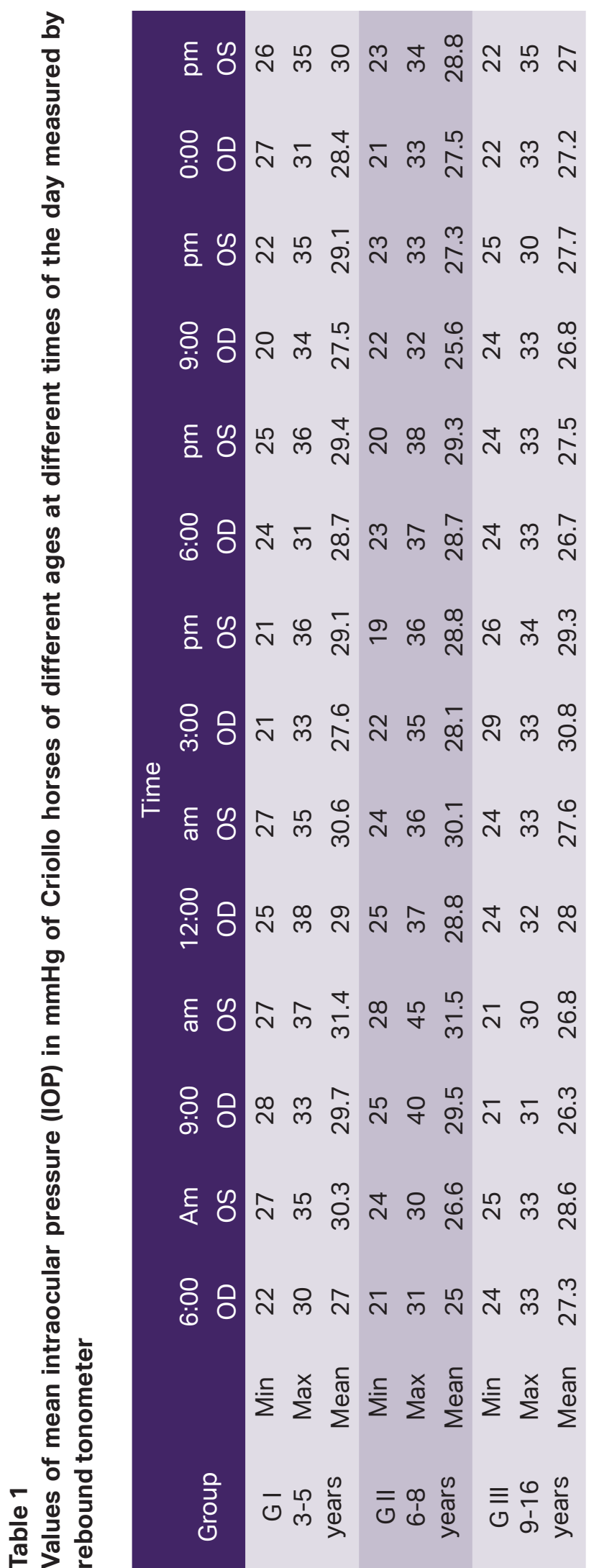

Portable tonometers have increasingly been used to measure IOP in different species, including rats, dogs, penguins, cats, pigeons and frogs, among others (Hibbs, Barrett, \& Dees, 2019). Previous studies demonstrated the great variation in IOP that exists within different animal species (Pereira et al., 2011). Normal IOP values measured using a rebound tonometer in horses oscillate between 10 and $34 \mathrm{mmHg}$ (Holve, 2012; Monk et al., 2017). The values obtained in this research are similar to those estimated in horses using a rebound tonometer (Holve, 2012; Andrade et al., 2016).

Rebound tonometry has frequently been used for these examinations in horses (Andrade et al., 2016; Monk et al., 2017; Dihel \& Bowden, 2020). This equipment has already been validated for equine species and the examination is well tolerated by the animals without the need to instil topical eye drops. Due to the ease of use of the equipment and previously published studies (Andrade et al., 2016; Hibs et al., 2019; Dihel \& Bowden, 2020), a rebound tonometer was chosen for this study, as it allows measurement of IOP in all horses and the tonometer is easy to handle. In the present experiment it was not necessary to use a lip twitch or to block the auricolupalpebral nerve in any animal. Andrade et al. (2016) observed that restraint of horses with a lip twitch increases IOP significantly.

The equipment used to measure IOP also interferes with the results obtained. Studies have already been carried out on horses comparing applanation and rebound tonometry. The authors concluded that TonoVet ${ }^{\circledR}$ overestimated IOP in comparison to the values obtained with a Tonopen $\mathrm{Avia}^{\circledR}$ applanation tonometer (Andrade et al., 2016). 
The age of the animals and the thickness of the cornea are among the factors that can change IOP (Ramsey et al., 1999). In the current study, corneal thickness assessment was not performed, but animals between 3 and 5 years old had mean IOP values significantly higher than those of horses between 9 and 16 years old. A study carried out with 129 Rocky Mountain horses showed no statistical difference between ages (Ramsey et al., 1999). The inverse relationship between IOP and the age of the animal has also been observed in llamas, alpacas and dromedaries (Marzok \& El-Khodery, 2015). The corneal thickness of horses increases with age, which would result in higher IOP values (Ramsey et al., 1999).

In the current study, no differences were found in IOP between genders, which is in agreement with a previous study in horses (Komáromy et al., 2006). Normally, IOP changes during the day as a function of circadian rhythm (Pereira et al., 2011). (Pereira et al., 2011) evaluated the IOP of rabbits using five daily measurements, from 6:00 am to 6:00 pm under a natural photoperiod, and found the highest IOP at 6:00 am. However, in later studies of the breed where constant regimes of light and darkness were applied, IOP was higher at the end of the scotophase (Piccione et al., 2010). Thus, there is still no consensus on the influence of circadian rhythm on IOP in animals (Pereira et al., 2011). This oscillation is a risk factor for carriers or individuals suspected of having glaucoma because in these cases it is necessary to monitor intraocular pressure to detect peaks and to manage anti-glaucoma therapy through the daily tension curve, with measurements every 3 hours starting at 6:00 am (Lima, Tecchio, Ferreira, Magarifuchi, \& Machado, 2010).
In this study, no differences were found between the measurements recorded at different times of the day. These results differed from those reported by Bertolucci, et al. (2009), who submitted the animals to three different light regimes, noting a peak in IOP at the end of the day and a drop in night-time values, in addition to detecting an endogenous rhythm that remained under conditions of constant darkness. In the present study, this was probably seen because the environment for tonometry was not completely isolated from external light. The results of the present study did not find a circadian fluctuation in IOP, as did Van Der Woerdt, Gilger, Wilkie, \& Strauch (1998), when performing tonometry on 20 horses from 8:00 am to 8:00 pm. Likewise, Herring, Pickett, Champagne, Troy and Marini (2000) performed tonometry on 11 healthy horses at 8:00 am and 4:00 pm and did not identify significant variations in IOP.

In healthy Criollo horses, IOP was not influenced by circadian rhythm, but older horses showed reduced IOP.

\section{Acknowledgements}

To Cabanha São Caetano for making the animals available for this research and to CAPES for granting the scholarship.

\section{Bioethics and biosecurity committee approval}

This study was approved by the Ethics Committee on the Use of Animals of the Federal University of Rio Grande do Sul, under protocol number 32754. 


\section{References}

Andrade, M. C. C. D., Hünning, P. S., Pereira, F. Q., Dutra, K. P., \& Pigatto, J. A. T. (2016). Lip twitch restraint on rebound tonometry in horses. Ciência Rural, 46(8), 1486-1490. doi: 10.1111/vop.12182

Association for Research in Vision and Ophthalmology (2016). Statement for the use of animals in ophthalmic and vision research (Revised Fall 2016). Retrieved from http://www.arvo.org/About_ARVO/ Policies/Statement_for_the_Use_of_ Animals_in_Ophthalmic_and_Visual_ Research/

Bertolucci, C., Giudice, E., Fazio, F., \& Piccione, G. (2009). Circadian intraocular pressure rhythms in athletic horses under different lighting regime. Chronobiology International, 26(2), 348-358. doi: 10.10 80/07420520902751035

Diehl, K., \& Bowden, A. C. (2020). Effe.ct of auriculopalpebral nerve block on equine intraocular pressure measured by rebound tonometry (TonoVet $\left.{ }^{\circledR}\right)$. Veterinary Ophthalmology, 23(2), 368-373. doi: 10. 1111/vop. 12735

Herring, I. P., Pickett, J. P., Champagne, E. S., Troy, G. C., \& Marini, M. (2000). Effect of topical $1 \%$ atropine sulfate on intraocular pressure in normal horses. Veterinary Ophthalmology, 3(2/3), 139-143. doi: 10.1046./j.1463-5224.2000.3230139.x

Hibbs, C. D., Barrett, P. M., \& Dees, D. D. (2019). Intraocular pressure reference intervals in eyes of clinically normal miniature donkeys (Equus africanus asinus). Veterinary Ophthalmology, 22(1), 24-30. doi: 10.1111/vop. 12561
Holve, D. L. (2012). Effect of sedation with detomidine on intraocular pressure with and without topical anesthesia in clinically normal horses. Journal of the American Veterinary Medical Association, 240(3), 308-311. doi: 10.2460/javma.240.3.308

Huet-Toral, F., Crooke, A., Martínez-Águila, A., \& Pintor, J. (2015). Melatonin receptors trigger cAMP production and inhibit chloride movements in nonpigmented ciliary epithelial cells. The Journal of Pharmacology and Experimental Therapeutics, 352(1), 119-128. doi: 10. 1124/jpet.114.218263

Komáromy, A. M., Garg, C. D., Ying, G. S., \& Liu, C. (2006). Effect of head position on intraocular pressure in horses. American Journal of Veterinary Research, 67(7), 1232-1235. doi: 10.2460./ajvr.67. 7.1232

Lima, F. P. A., Tecchio, L. T., Ferreira, L. A., Magarifuchi, M., \& Machado, R. G. (2010). Evaluation of the intraocular pressure behavior in patients with assimetric primary open-angle glaucoma submitted to ibopamine provocative test. Revista Brasileira de Oftalmologia, 69(3), 165169. doi: 10.1590/S0034-72802010000 300005

Marzok, M. A., \& El-Khodery, S. A. (2015). Intraocular pressure in clinically normal dromedarycamels (Camelusdromedarius). American Journal of Veterinary Research, 76(2), 149-154. doi: 10.2460/ajvr. 76.2.149

Monk, C. S., Brooks, D. E., Granone, T., GarciaPereira, F. L., Melesko, A., \& Plummer, C. E. (2017). Measurement of intraocular pressure in healthy anesthetized horses during hoisting. Veterinary Anaesthesia and Analgesia, 44(3), 502-508. doi: 10. 1016/j.vaa.2016.10.001 
Pereira, F. Q., Bercht, B. S., Soares, M. G., Mota, M. G. B. da, \& Pigatto, J. A. T. (2011). Comparison of a rebound and an applanation tonometer for measuring intraocular pressure in normal rabbits. Veterinary Ophthalmology, 14(5), 321-326. doi: 10.1111/j.1463-5224.2011.00879

Piccione, G., Giannetto, C., Fazio, F., \& Giudice, E. (2010). Influence of different artificial lighting regimes on intraocular pressure circadian profile in the dog (Canis familiaris). Experimental Animals, 59(2), 215-223. doi: 10.1538/expanim.59.215
Ramsey, D. T., Hauptman, J. G., \& PetersenJones, S. M. (1999). Corneal thickness, intraocular pressure, and optical corneal diameter in Rocky Mountain Horses with cornea globosa or clinically normal corneas. American Journal of Veterinary Research, 60(10), 1317-1321.

Van der Woerdt, A., Gilger, B. C., Wilkie, D. A., \& Strauch, S. M. (1995). Effect of auriculopalpebral nerve block and intravenous administration of xylazine on intraocular pressure and corneal thickness in horses. American Journal of Veterinary Research, 56(2), 155-158. 